\title{
Diyet Blok Tip Eritme Peyniri Üretiminde Yumurta Kullanım Olanaklarının Araştırılması
}

\author{
Hasan Cankurt ${ }^{1 *}$, Ramiz Yüksel, ${ }^{2}$ Hasan Yetim $^{3}$ \\ ${ }^{1}$ Kayseri Üniversitesi, Safiye Çıkrıkçıoğlu M.Y.O. Gıda İşleme Bölümü, Kayseri, Türkiye (ORCID: 0000-0002-3842-6539) \\ ${ }^{2}$ Erciyes Üniversitesi, Fen Blimleri Enstitüsü Gıda Mühendisliği A.B.D., Kayseri, Türkiye \\ ${ }^{3}$ İstanbul Sabahattin Zaim Üniversitesi, Mühendislik ve Doğa Bilimleri Fakültesi, Gıda Mühendsiliği Bölümü, İstanbul, Türkiye
}

(İlk Geliş Tarihi 12 Mart 2019 ve Kabul Tarihi 28 Mart 2019)

(DOI: $10.31590 /$ ejosat.538858)

ATIF/REFERENCE: Cankurt, H., Yüksel, R. \& Yetim, H.. (2019). Diyet Blok Tip Eritme Peyniri Üretiminde Yumurta Kullanım Olanaklarının Araştırılması. Avrupa Bilim ve Teknoloji Dergisi, (15), 579-590.

\section{$\ddot{O} \mathbf{z}$}

$\mathrm{Bu}$ çalışmada, diyet ürün ihtiyacından doğan talebin karşılanması amacıyla blok tip eritme peynirlerinde yumurta ilavesi ile yağ azaltma imkanları araştırılmıştır. Araştırmada, yağı alınmış sütte yağ ikame maddeleri yerine tam tavuk yumurtası kullanılarak yağsız blok tip eritme peynir üretimi gerçekleştirilmiştir. Peynirde erime ve sünmenin gerçekleşebilmesi için telemenin pH's1 5,30'a getirildikten sonra (yumurtasız), \%5, \%7.5 ve \%10 oranlarında bütün yumurta eklenen karışım, Stephan tipi buhar ceketli bir eritme makinasında eritilmiştir. Elde edilen peynirlerin blok hale gelmesi için kalıplara konulmuş ve bir gece bekletildikten sonra kalıptan çıkarılmıştır. Daha sonra elde edilen (kontrol) ve tavuk yumurtası içeren eritme peynirleri, 0., 30. ve 60. günlerde analize alınmak üzere $+4{ }^{\circ} \mathrm{C}$ 'de depolamaya alınmış ve örneklerin bazı fizikokimyasal, tekstürel ve duyusal özellikleri analiz edilmiştir. Sonuçta, tavuk yumurtası kullanımının yağsız blok tipi eritme peynirlerinde toplam kuru madde değerlerini artırmıştır. Depolama boyunca eritme peynir örneklerinde $\mathrm{pH}$ düşüşüne, titrasyon asitliği değerlerinde ise önemli bir artışa neden olduğu belirlenmiştir. Aynı zamanda örneklerin, renk değerlerinde $\left(L^{*}\right.$ ve $\left.b^{*}\right)$ artış ise istatistiki açıdan önemsiz bulunurken, a* değeri yumurta miktarının artmasıyla doğru orantılı olarak artmıştır. Tekstürel analiz sonuçlarına göre en yüksek sertliğe sahip peynir çeşidinin kontrol peyniri olduğu tespit edilirken yumurta kullanımının, peynirin sertlik değerlerinde sebep olduğu düşüş de istatistiki açıdan önemsiz bulunmuştur. Duyusal değerlendirme sonuçlarına göre genel beğeni yönü ile en yüksek puanı, \% 7.5'lik yumurta ilaveli örnekler almıştır. Genel olarak yumurta kullanımı ile örneklerin hem görünüşü ve hem de tadı olumlu yönde etkilenmiştir. Sonuç olarak, yağı alınmış sütlerle blok tip eritme peyniri üretiminde, süt yağı yerine \% 7.5 civarında tam tavuk yumurtasının yağ ikamesi olarak kullanımının uygun olabileceği anlaşılmıştır.

Anahtar Kelimeler: Eritme peyniri, Yağ ikame maddesi, Tüm yumurta

\section{Investigation on Using Possibilities of Egg in the Production of Diet Block Type Melting Cheese}

\begin{abstract}
In this study, decreasing fat capability by adding egg in block-type melted cheese in order to meet the demand arising from the dietary product requirements. In the research, by using full chicken eggs, fat-free block-type melting cheese were produced in slim milk instead of using skim milk. In order to achieve melting and roping in the cheese, after the $\mathrm{pH}$ of the curd was brought to 5.30, the mixture which was added whole egg at the rates of 5\%,7.5\% and 10\%, was dissolved in a Stephan type steam jacket melting machine The cheeses were put into the molds to block and after one night they were removed from the mold. Melting cheeses containing simple (control) and chicken eggs were then stored at $+4{ }^{\circ} \mathrm{C}$ for analysis on days 0,30 and 60 and some physicochemical, textural and sensory characteristics of the samples were analyzed. As a result, the use of chicken eggs increased the total dry matter values of
\end{abstract}

\footnotetext{
* Sorumlu Yazar: Kayseri Üniversitesi, Safiye Çıkrıkçığlu MYO Gıda İşleme Bölümü, Kayseri, Türkiye, ORCID: 0000-0002-3842-6539, hcankurt@erciyes.edu.tr
} 
lean block type melting cheeses. During the storage, it was observed that the melting cheese samples had a decrease in pH and an increase in titration acidity values At the same time, the increase in color values ( $\mathrm{L} *$ and $\mathrm{b} *$ ) were not statistically significant. The value of $\mathrm{a}^{*}$ increased in proportion to the increase in egg quantity. According to the results of the textural analysis of the highest hardness of the cheese type of the basic melting cheese, while the use of eggs, the hardness of cheese caused by the decrease in the value of cheese was found to be insignificant. According to the results of sensory evaluation, the highest score was taken with $7.5 \%$ egg addition. In general, both the appearance and taste of the samples were affected positively by the use of eggs. As a result, it was understood that the use of whole-chicken egg instead of milk fat could be suitable as an fat substituent in the production of block type melting cheese with skim milk.

Keywords: Melting cheese, Fat substituent, Whole egg

\section{Giriş}

Peynir; farklı yağ oranlarına sahip sütün, enzim veya laktik asit ile pıhtılaştırılıp, oluşan pıhtıdan peynir altı suyunun uzaklaştırılması, pıhtının şekillendirilmesi ve tuzlanması ile hazırlanan süt ürünü olarak tanımlanmaktadır (Tekinşen ve Tekinşen, 2005). Çeşitli kaynaklara göre dünyada yaklaşık 2 bin ile 4 bin arasında peynir türünün olduğu bildirilmiştir. Yapılan bir araştırmada Türkiye'de 193 farklı peynir türünün olduğu belirtilmiştir (Anonim, 2016).

Türkiye'de en çok tüketilen peynirlerin başında beyaz peynir ve kaşar peyniri olduğu bildirilmiştir (Çelik ve Uysal, 2009). Özellikle son yıllarda piyasada bulunan kaşar peynirlerinin büyük bir kısmının blok tip eritme peyniri olduğu dikkate alınırsa, Türkiye'de en çok satılan peynirlerin beyaz peynir ve blok tip eritme peyniri olduğu anlaşılmaktadır. Piyasada taze kaşar peyniri diye satılan peynirlerin nerede ise tamamı emülsifiye edici tuzlar kullanılarak üretilmektedir. Bu tuzların kullanımı ile üretilen ürüne blok tip eritme peyniri denmektedir (Cankurt, 2015). Eritme peynirinin diğer peynirlere göre bazı avantajları vardır. Eritme peyniri, emülsiyonun kırılması sonucu, yağ ayrılmasına uğramadan oda sıcaklığında saklanabilmektedir. Isıl işlem uygulanarak patojen mikroorganizmalar yok edildiği için güvenle tüketilen bir peynirdir. Olgunluk derecesi farklı olan peynirlerin karıştırılması ile istenilen tat ve aromaya sahip ürün elde etmek mümkün olmaktadır. Ayrıca aşırı derecede olgunlaşmış ve uzun süre muhafaza edilmiş peynirler, eritme peyniri karışımında kullanılarak değerlendirilme imkânı bulmaktadır (Hui, 1992). Süt yağı, enerji vermenin yanında süt ürünlerinde tekstür, renk ve lezzet oluşumlarında önemli rol oynar (Rudan vd., 1999). Peynir üretiminde yağ miktarı azaltıldığında, peynirin duyusal ve fiziksel özellikleri olumsuz yönde etkilenir. Yağı azaltılmış peynirlerde; sertliğin artması, kauçuksu doku, acılık, yavansı tat ve istenmeyen renk oluşumu görülür. Yağı azaltılan peynirlerde ortaya çıkan bu gibi kusurların önüne geçmek için, üretim prosesinin değiştirilmesi, yardımcı starter kültürlerle yă̆ ikame edici maddelerin kullanılması önerilmektedir (Drake ve Swanson, 1995; Mistry, 2001). Yă̆ ikame maddeleri, gidalarda yă̆ yerine kullanılan ve kaloriyi azaltan katk1 maddeleridir. Yağ ikame edici maddeler, yağ taklidi maddeler (fat mimetics) ve yağ benzeri maddeler (fat substitutes) şeklinde sınıflandırılır ve bu maddelerin kombinasyonları da kullanılır (Huygbaert vd., 1996). Gıdalardaki yă kaynaklı tüketici kaygılarını gidermek amacıyla üretici firmalar yağ ikame edici maddelerden yararlanarak tam yağlı ürünlere benzer ürünler geliştirmektedirler. Yağ benzeri adındaki maddeler, lipazın katalizlediği hidroliz tepkimelerine direnci olan, ester bağıyla bağlanmış yağ asidi kökenli ürünler içerir. Bu ürünler gıdaya yağ benzeri fonksiyonel özellikler kazandırırlar (Huyghebaert, 1996). Bu çalışmada yumurta kullanımıyla yağsız blok tip eritme peynirine fonksiyonel özellik kazandırılması hedeflenmiştir. Bu yöntemle, tüketicilere yağ oranı düşük yeni bir diyet ürün kazandırılırken aynı zamanda bu ürünün yüksek besin değerine sahip olması hedeflenmiştir.

\section{Materyal ve Metot}

\subsection{Materyal}

Eritme peynir üretiminde, Erciyes Üniversitesi Tarımsal Araştırma Merkezi çiftliğinden elde edilen inek sütleri kullanılmıştır. Çiftlikten alınan çiğ sütlerin kontrolleri (Duyusal testi, pH, SH, brix, \% yăg oranı, antibiyotik testi ve peroksit testi) yapılarak, sütün kalitesi belirlenmiştir. Eritme peynirinin hamuruna katılan yumurtalar, Tarım Gıda ve Yumurtacılık Limited Şirketinden (Kayseri) temin edilmiş olup A sınıfı yumurtalar kullanılmıştır. Kaşar starter kültürü, İntermak A.Ş. firmasından (Konya) satın alınmıştır. Eritme tuzu olarak fosforik asidin sodyum tuzları (Casomel marka, Belçika) kullanılmıştır. Sütlerin özellikleri tespit edildikten sonra sütün yağı seperatörle tespit edilebilir seviyenin altına kadar alınmış ve üretimde yağsız süt kullanılmıştır.

\subsection{Metot}

Araştırmada üretilen eritme peynir örnekleri, Kayseri Üniversitesi Safiye Çıkrıkçıŏlu Meslek Yüksek Okulu Gıda Teknolojisi Pilot Uygulama Merkezi'nde üretilmiştir. Üretim aşamaları aşağıda sırasıyla verilmiştir Peynir üretimi için alınan ve ön kontrolleri yapılan çiğ süt kaba bir filtrasyondan geçirilerek, elektrikli krema separatörü ile yağı alınmış ve bu sütler peynir üretiminde kullanılmıştır. Starter kültürlerin aktive edilmesi amacıyla önce yağsız süt tozundan \%12 kuru maddeli rekonstitüe sütler hazırlanmış, 50 ml'lik cam şişeler halinde $90^{\circ} \mathrm{C}^{\prime} \mathrm{de} 30 \mathrm{dk}$ süreyle 1 sıl işleme tabi tutulmuştur. Cam şişelerin içerisine liyofilize peynir starter kültürlerinden eklenerek, süt pıhtılaşıncaya kadar $35-37^{\circ} \mathrm{C}$ 'de inkübasyona bırakılmıştır. Daha sonra aktif edilen kültürler 1 'er litrelik erlenlerde, $90^{\circ} \mathrm{C} 30 \mathrm{dk}$ süre ile pastörize edilmiş rekonstitüe sütlere $\% 2$ oranında eklenerek $35-37^{\circ} \mathrm{C}$ inkübasyona bırakılarak kültürler peynir üretime hazır hale getirilmiştir.

\subsubsection{Eritme Peynir Üretimi}

Peynir üretimi amacıyla yağı alınan süt, buharlı çift cidarlı bir kazanda $65^{\circ} \mathrm{C}$ 'de 30 dakika 1sıl işleme tabi tutulmuştur ve süt soğutularak mayalama sıcaklığına $\left(37^{\circ} \mathrm{C}\right)$ getirilmiştir. Sütün içine önceden hazırlanan stater kültürden \% 2 oranında olacak şekilde ilave edilmiştir. Maya testi sonucuna göre maya oranı ayarlanarak mikrobiyal rennetle (Fermento 220, Kuvveti: 220 IMCU/ml, İntermak A.Ş, Konya) 1 saat süre ile mayalanma süresi gerçekleştirilmiştir. Mayalanma süresi sonunda mayalama tankında oluşan 
peynir pıhtısı kırılmış ve kırılan telemenin toplanması için tankın sıcaklığı $42^{\circ} \mathrm{C}$ 'ye kadar tekrar yükseltildikten sonra, sonrasında teleme süzme teknesinde süzülerek suyu alınmıştır. Suyunu bırakan telemenin üzerine ağırlık konularak, pH değeri 5,80'e gelinceye kadar starter kültürlerle fermantasyon yoluyla asitlendirilmiş sonrasında pH değeri 5,40 da iken doğrama yapılmıştır. pH değeri tekrar 5,25'e gelince eritme aşamasına geçilmiştir. pH değeri 5.25'e gelen teleme dört eşit parçaya bölünmüştür. Bölünen her bir teleme parçası buharlı eritme kazanına alınıp üzerine eritme tuzları (\% 0.7 oranında 2185 no'lu eritme tuzu, \% 0.3 oranında 3112 no'lu eritme tuzu) ve \% 2 oranında sofra tuzu ilave edilmiştir. Karışım ısıtılmaya başlanmış ve $50^{\circ} \mathrm{C}$ de iken her partiye daha önce mikserden geçirilmiş olan farklı oranlardaki (\% 5, \% 7.5 ve \% 10’luk) tüm yumurtalar eklenmiştir. Kontrol numunesine yumurta eklenmemiştir. Yumurtaların $50^{\circ} \mathrm{C}$ de eklenmesinin nedeni, yumurta baştan ilave edilirse uzun süre sıcaklığa maruz kalacağından yumurtanın pişmesi ile pütürlü yapının oluşabilmekte, $75^{\circ} \mathrm{C}$ 'de iken ilave edilincede homojen şekilde karışmamaktadır. Tüm örnekler $75^{\circ} \mathrm{C}$ 'de 5 dakika boyunca eritme kazanında haşlanmıştır. Hazırlanan peynirler şekil alması için kalıplara dökülmüş ve kalıplar hamur soğuduktan sonra sökülerek oda sıcaklığında 8 saat boyunca yüzey kurumasına bırakılmıştır. Sonrasında vakum paketleme yapılarak peynirler $+4{ }^{\circ} \mathrm{C}$ 'deki soğuk depoya alınmıştır (Cankurt, 2015). Daha sonra elde edilen peynirlerin 1., 30. ve 60. günlerde analizleri yapılmıştır.

\title{
Çiğ Süt
}

\author{
Çiğ Süt Kalite Kontrol Analizleri \\ $\downarrow$ \\ Sütün $65^{\circ} \mathrm{C} \pm 1^{\circ} \mathrm{C}$ de 30 dk pastörizasyonu \\ $\downarrow$ \\ Sütün $37^{\circ} \mathrm{C} \pm 1^{\circ} \mathrm{C}$ ye soğutulması \\ $\downarrow$ \\ $37^{\circ} \mathrm{C}$ de $60 \mathrm{dk}$ mayalama \\ (Starter kültür ve maya ilavesi) \\ $\downarrow$ \\ Pıhtı Kırımı ve dinlendirme (15 dk) \\ $\downarrow$ \\ Pıhtının $42^{\circ} \mathrm{C} \pm 1^{\circ} \mathrm{C}^{\prime}$ ye kadar isıltılması \\ $\downarrow$ \\ Peyniraltı suyunun uzaklaştırılması ve baskılama \\ $\downarrow$ \\ Telemeyi pH 5.25'e kadar asitlendirme \\ $\downarrow$ \\ $\downarrow$ \\ Kalıplama ve Kurutma \\ $\downarrow$ \\ Vakum Paketleme ve Depolama $\left(+4^{\circ} \mathrm{C}\right)$
}

Eritme Tuzu ve Yumurtalı peynirlere yumurta ilavesi $(\% 5, \% 7.5$ ve $\% 10) 7^{\circ} \mathrm{C}$ de 5 dk eritme

Şekil 1. Eritme peyniri üretimi işlem basamakları

\subsubsection{Hammadde Analizleri}

\subsubsection{Süt Analizleri}

Eritme peyniri üretiminde kullanılan çiğ sütün toplam kuru madde oranı kurutma yöntemiyle, yă̆ analizi Gerber santrifüj yöntemiyle, $\mathrm{pH}$ analizi $\mathrm{pH}$ metre ile (Hanna-Instrument $\mathrm{pH}$ microprocessor) ve toplam asitliği titrasyon yöntemi ile yapılmıştır (Kurt vd. 1996). Sütün bazik madde tayini rozalik asit testi ile toplam azot testi miktarı ise kjedahl yöntemiyle yapılmıştır (Metin, 2010). 
Sütün briks değeri ise, milkana marka çok parametreli süt analiz cihazıyla ölçülmüşsür (Çavuş, 2015). Yumurta ile ilgili analiz yapılmamıştır. Yumurtanın bileşimi ile ilgili bilgiler literatürden elde edilmiştir.

\subsubsection{Eritme Peynirinde Yapılan Fizikokimyasal Analizler}

Peynir de titrasyon asitliği tayini Metin, (2010)'un yöntemine göre yapılmıştır. Peynirdeki toplam kuru madde tayini, gravimetrik yöntemle ölçülmüştür Sabit tartıma getirilen peynirler (Kurt vd., 1996)'ya göre yapılmıştır. Peynirlerdeki yağ oranı, Gerber yöntemi ile yapılmıştır. Yağ oranı belirlenen peynirlerin toplam kuru maddedeki yăg oranı formülle hesaplanmıştır (Kotterer ve Münch, 1978). Peynirlerdeki protein oranları, Kjeldahl yöntemi ile üründeki azot miktarının belirlenmesi ve 6.38 sabit çarpım faktörü kullanarak hesaplanmıştır (IDF, 1993). Peynirlerdeki tuz oranları, Mohr yöntemiyle (Metin, 2010) göre yapılmıştır. Peynirlerin renk analizi, renk tayin cihazı ile (Lovinbond Reflectance Tintometer 962, Kanada) belirlenmiştir (Mitsumoto vd, 2005).

\subsubsection{Peynirlere Uygulanan Tekstürel Analizler}

Peynir örneklerinin tekstürel özellikleri (Sertlik, İç Yapışkanlık, Dış Yapışkanlık, Elastikiyet, Sakızımsılık ve Çiğnenebilirlik), TAXT Plus Texture Analyser (United Kingdom) doku ölçüm cihazı yardımıyla belirlenmiş̧ir. Analize tabi tutulan örnekler $2.0 \mathrm{~cm}$ boyutlarında küpler halinde kesilmiştir. Örnekler üzerine $30 \mathrm{~kg}$ 'lık load cell kullanılarak $1 \mathrm{~mm} / \mathrm{sn}$ sıkıştırma hızı ile $10 \mathrm{sn}$ boyunca iki kez sıkıştırma işlemi ile örneklerin doku profil analiz parametreleri belirlenmiştir (Ahmed vd., 2005).

\subsubsection{Peynirlere Uygulanan Duyusal Analizler}

Eritme peynirlerin duyusal kalitesini tespit etmek amacıyla hedonik skala yöntemine göre duyusal analiz yapılmıştır. Belirli zaman dilimlerinde 8 panelist tarafindan peynirlerin bazı özellikleri değerlendirilmiştir (Yetim, 2001).

\subsection{6. İstatistiksel Analizler}

Telemeye farklı oranlarda yumurta ilavesiyle elde edilen eritme peynirlerinin kalite özelliklerini belirlemek ve karşılaştırmak amacıyla, Windows tabanlı Minitab 18 istatistik programı kullanılarak değerlendirme yapılmıştır. Tek faktör varyans analizine tabi tutulan veriler, \%95 güven aralıkları ve Fisher LSD Metodu Gruplama Bilgisi yöntemiyle karşılaştırma testi kullanılarak belirlenmiştir.

\section{Araştırma Sonuçları ve Tartışma}

\subsection{Fizikokimyasal Özellikler}

Bu araştırmada yağı azaltılmış peynir üretimi amacıyla yağssz sütten üretilen telemeye belirli oranlarda bütün yumurta ve emülsifiye edici tuzlar katılarak eritme peyniri üretilmiş ve peynirler vakum paketlemeye tabi tutulduktan sonra belirli sürelerde depolanmıştır. Başlangıç ve depolama süreleri sonunda deneme peynirlerinin bazı fizikokimyasal, tekstürel, ve duyusal özellikleri incelenmiştir. Araştırma sonucunda blok tip eritme peynirlerine ait tablolar halinde aşağıda verilmiştir.

Yağsız sütten üretilen ve vakum paketlemeye tabi tutulan eritme peynirlerinin toplam kuru madde, tuz, kuru maddedeki tuz oranlarının depolama boyuncanın değişmeyeceği öngörüldüğünden bu parametrelerin sadece birinci gün analizleri yapılmıştır.

Araştırmada \%5, 7.5 ve 10 oranlarında tüm yumurta ilavesiyle elde edilen eritme peynirleri ve kontrol peynirlerinin (yağsız ve yumurtasız), toplam kuru madde, tuz ve kuru maddedeki tuz oranlarına ait sonuçlar ilk gün analizleri Tablo 3.1 de verilmiştir.

Tablo 3.1. Peynirlerin depolama boyunca ölçülen toplam kuru madde, tuz ve kuru maddedeki tuz oranları

\begin{tabular}{|c|c|c|c|c|}
\hline & $\%$ Yumurta & $\operatorname{TKM}(\%)$ & $\operatorname{Tuz}(\%)$ & TKM de Tuz (\%) \\
\hline \multirow{4}{*}{ 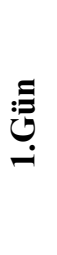 } & Kontrol & $43.58^{C_{ \pm}} \pm 0.14$ & $1.78^{\mathrm{B}} \pm 0.01$ & $4.08^{\mathrm{A}} \pm 0.02$ \\
\hline & 5 & $45.15^{\mathrm{B}} \pm 0.07$ & $1.77^{\mathrm{C}_{ \pm}} 0.01$ & $3.92^{\mathrm{C}} \pm 0.01$ \\
\hline & 7.5 & $45.29^{\mathrm{B}} \pm 0.28$ & $1.79^{\mathrm{A}} \pm 0.01$ & $3.95^{\mathrm{B}} \pm 0.02$ \\
\hline & 10 & $46.71^{\mathrm{A}} \pm 0.22$ & $1.79^{\mathrm{A}} \pm 0.01$ & $3.83^{\mathrm{C}} \pm 0.02$ \\
\hline
\end{tabular}

Toplam kuru madde değerlerinde en yüksek değere sahip örnek, \%10 yumurta ilaveli eritme peynir örneği olurken; en düşük değere sahip örnek ise kontrol örneği örneği olmuştur. Beklenildiği gibi peynirlerde yumurta oranı arttıkça toplam kuru madde oranının da arttı̆̆ı gözlemlenmiştir. Analizi yapılan eritme peynirlerinin \% tuz oranları, birbirlerine yakın bulunmuştur. Toplam kuru maddedeki tuz oranlarının ise örneklerin nem içeriğine göre değişkenlik gösterdiği belirlenmiştir. Toplam kuru maddedeki tuz değerleri açısından örnekler arasındaki fark lar istatistiksel açıdan önemli $(\mathrm{p}<0,05)$ bulunmuştur. Eritme peyniri üzerine bir araştırmada, vakumlanmış kaşar benzeri peynirlerin toplam kuru madde oranlarında depolama süresince önemli bir değişmenin görülmediği bildirilmiştir (Metin ve Öztürk, 1991; Koca ve Metin, 2003; Keçeli vd., 2006; Çürük, 2006). Piyasadaki eritme peynirlerinin kuru madde değerleri \% 44 ile 63 arasında değişmektedir (Cankurt, 2015). Bu araştırmada yağsız eritme peynirine ilave edilen yumurta oranı arttıkça peynirin \% toplam kuru madde oranlarınında da artış gözlemlenmiştir. Bu artışın telemeye katılan yumurtadan kaynaklandığı anlaşılmıştır. Eritme peynirindeki toplam kuru madde miktarı ile ilgili birçok araştırma yapılmıştır. Bulunan değerler \%46.17 (Yöney, 1962 ); \%42.94 ile 
\%65.67 (Dolun, 1974); \%42.59 ile \%48.8 arasında (Mahfouz vd., 1986); \%45,06 (Alper, 2012); ve \% 46.7-51.6 (Özkan, 2012) ve $\% 40,11$ ile \%43,29 arasında (Doruk, 2018) şeklindedir. Tablo. 1'de verilen ve çalışmamızda bulunan değerler Yöney, (1962); (Mahfouz vd., (1986) ve Alper, (2012) tarafindan elde edilen \% toplam kuru madde değerlerine çok yakın bulunmuştur ve daha önceki araştırmaların sonuçları ile de benzerlik göstermektedir. Piyasada bulunan eritme peynirlerinin kuru madde değerleri \% 44 ile 63 arasında değişmektedir (Cankurt, 2015). Eritme peynirinde kuru madde değerlerinde bu kadar farklılık görülmesinin nedeni üretimde kullanılan çiğ sütün asitliliği, telemenin baskılama süresi ve peynir altı suyuna geçen besin maddelerinden ileri gelmektedir. Eritme peynirlerinin kuru madde içeriğindeki farklılıkların sebebinin hammadde, maya oranı, mayalanma süresi, baskılanma ağırlığı ve süresi olabileceği belirtilmiştir (Fırat, 2006).

Eritme peynirinde tuz oranı; ilk gün analizlerinde $\% 1.77$ ile $\% 1.79$ arasında değerler bulunmuştur. Peynirler aynı formülasyon ve teknikle üretildiği için, peynir kitlelerinin içerdiği \% tuz oranları birbirine yakın bulunmuştur. Eritme peynirinde tuz miktarı ile ilgili yapılan çalışmalarda tuz oranlarında farklılıklar görülmektedir. Yapılan önceki araştırmalara göre eritme peynirlerinde tuz oranı, \% 3.26 (Öztek, 1989); \% 3.16 (Ayar, 1991); \% 1.91 (Keçeli vd., 2006); \% 4.09 (Ayar vd., 2006) ve \% 1.69-3.22 (Fırat, 2006) arasında bulunmuştur. Peynirdeki tuz oranı üretim metotlarına ve tüketicinin taleplerine göre değişkenlik gösterebilir. Bundan dolayı tuz oranını diğer peynirler ile karşılaştırmanın sağlıklı sonuçlar vermeyeceği açıktır (Cankurt, 2015). Göncü (2018), bazı baharat çeşitlerinin dilimlenebilir eritme peyniri üretiminde kullanım olanaklarının araştırılması amacıyla yaptı ğı çalışmada eritme peynirinin toplam kuru maddedeki tuz oranını 3.72 ile 4.23 arasında bulmuştur. Göncü (2018)'in sonuçları bizim çalışmamızla benzerlik göstermektedir.

\section{Tablo 3.2. Peynirlerin depolama boyunca ölçülen $\mathrm{pH}$, Azot ve Toplam asitlik değeri}

\begin{tabular}{|c|c|c|c|c|}
\hline & $\%$ Yumurta & 1. Gün & 30. Gün & 60. Gün \\
\hline \multirow{4}{*}{ 풀 } & Kontrol & $5.79^{\mathrm{Aa}} \pm 0.02$ & $5.74^{\mathrm{Aab}} \pm 0.02$ & $5.71^{\mathrm{Ab}} \pm 0.01$ \\
\hline & 5 & $5.80^{\mathrm{Aa}} \pm 0.02$ & $5.76^{\mathrm{Aab}_{ \pm}} \pm 0.02$ & $5.75^{\mathrm{Ab}} \pm 0.01$ \\
\hline & 7.5 & $5.81^{\mathrm{Aa}} \pm 0.02$ & $5.78^{\mathrm{ABb}} \pm 0.02$ & $5.75^{\mathrm{Ab}} \pm 0.00$ \\
\hline & 10 & $5.81^{\mathrm{Ba}} \pm 0.02$ & $5.78^{\mathrm{Bb}} \pm 0.02$ & $5.76^{\mathrm{Bc}} \pm 0.01$ \\
\hline \multirow{3}{*}{$\frac{\overrightarrow{8}}{4}$} & Kontrol & $5.24^{\mathrm{Ca}} \pm 0.04$ & $5.26^{\mathrm{Bb}} \pm 0.02$ & $5.26^{\mathrm{Bb}} \pm 0.04$ \\
\hline & 5 & $5.27^{\mathrm{Bb}} \pm 0.04$ & $5.30^{\mathrm{Ba}} \pm 0.02$ & $5.31^{\mathrm{Ab}_{ \pm}} \pm 0.02$ \\
\hline & 7.5 & $5.27^{\mathrm{Bb}} \pm 0.04$ & $5.32^{\mathrm{Ab}} \pm 0.04$ & $5.33^{\mathrm{Ab}} \pm 0.04$ \\
\hline \multirow{5}{*}{ 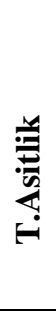 } & 10 & $5.30^{\mathrm{Ba}} \pm 0.04$ & $5.34^{\mathrm{Aa}} \pm 0.02$ & $5.34^{\mathrm{Aa}} \pm 0.04$ \\
\hline & Kontrol & $0.19^{\mathrm{Cb}} \pm 0.01$ & $0.19^{\mathrm{Ab}} \pm 0.01$ & $0.19^{\mathrm{Aa}} \pm 0.01$ \\
\hline & 5 & $0.19^{\mathrm{Cb}_{ \pm}} \pm 0.01$ & $0.19^{\mathrm{Ab}} \pm 0.01$ & $0.19^{\mathrm{Aa}} \pm 0.01$ \\
\hline & 7.5 & $0.20^{\mathrm{Bb}} \pm 0.01$ & $0.20^{\mathrm{Ab}} \pm 0.01$ & $0.20^{\mathrm{Aa}} \pm 0.01$ \\
\hline & 10 & $0.21^{\mathrm{Bb}} \pm 0.01$ & $0.21^{\mathrm{Ab}} \pm 0.01$ & $0.21^{\mathrm{Aa}} \pm 0.01$ \\
\hline
\end{tabular}

Peynir örneklerinin toplam asitlik değerlerinde depolama boyunca artış gözlemlenmiştir. Örneklerde yumurta oranı arttıkça asitliğin de arttığı görülmüştür, peynir üretiminde kullanılan starter kültürlerinin ürettikleri laktik asit, toplam asitliği artırırken; $\mathrm{pH}$ değerini de düşürmüştür. Eritme peyniri örneklerinin bileşimi, yumurta ilaveli örneklerin içerdiği yumurta haricinde aynıdır. Bundan dolayı peynirde yumurta kullanımının starter kültürlerin faaliyetini yavaşlattığı söylenebilir. Bazı araştırmacılar tarafından kaşar ve benzeri peynirlerde depolama süresince asitlik değerlerinde sürekli artış olduğu belirtilmiştir (Özdemir, 1997; Çağlar ve Çakmakç1, 1998). Göncü (2018), eritme peyniri üzerine yaptı̆̆ çalışmada \%1.14-1.83 arasında değerler bulmuş ve depolama sonunda bu değerlerin arttığını bildirmiştir. Kaşar peyniri üzerine yapılan diğer bazı çalışmalarda, titrasyon asitliğinin depolama boyunca arttığı bildirilmiştir (Atamer vd., 1999; Güven vd, 2004; Yasar ve Guzeler, 2011; Çetinkaya, 2012; Çelikel, 2017). Bizim çalışmamızda da benzer olarak asitliğin depolama sonucunda sonunda arttı̆̆ görülmüştür. Yapılan bazı araştırmalarda toplam asitlik değerleri, \%0.23 ile \%0.69 aralığında (Keleş vd., 2001); \%0.42 (Öksüztepe vd. 2009); \%0.49-0.72 aralı̆ı̆ında (Güven vd., 2002); \%0.42 (Öksüztepe vd. 2009) ve \%0.279 ile \%1.050 aralığında (Çavuş, 2015); \%0.23 ile \%0.69 aralığında (Keleş vd., 2001) bulunmuştur. Çalışmamızda bulunan değerlerin Keleş vd. (2001) tarafından yapılan çalışmada elde edilen değerler ile benzer olduğu görülmüştür.

Depolama boyunca en yüksek pH değerine \%10 ilaveli eritme peynir örneği sahip olurken en düşük değere ise kontrol örneğinin sahip olduğu görülmüştür. Peynirlerin yapısı, lezzeti ve raf ömrü üzerine etki eden en önemli faktörlerden birisi de şüphesiz pH değeridir. TS 2176 Eritme Peyniri Standartına göre eritme peynirlerindeki pH değeri en düşük 5.5 olmalıdır. Saldamlı (1987), eritme peynirlerinde ürünün yapısı ve dayanıklılı̆g i için ortalama pH değerinin 5.4-5.8 arasında olması gerektiği görüşünü savunmaktadır. Eritme peynirinde $\mathrm{pH}$ değerleri 5.7 ile 5.8 arasında değişkenlik göstermiş ve depolama boyunca $\mathrm{pH}$ değerlerinde düşüş meydana gelmiştir. Çalışmamızda örneklerin $\mathrm{pH}$ değerinin yüksek çıkmasının nedeninin, peynir üretiminde kullanılan emülsifiye edici tuzların, ortamın $\mathrm{pH}$ değerini artırmasından kaynaklandığı düşünülmektedir. Çünkü emülsifiye edici tuzlar bulundukları ortamın $\mathrm{pH}$ 'sını yükseltirler. Aynı zamanda peynirlere katılan starter kültürlerin ürettikleri laktik asit, ortamın $\mathrm{pH}$ 'sını düşürmektedir. Farkye ve Fox (1990), peynirin türüne göre değiş̧kenlik göstermekle birlikte pıhtıdaki laktozun parçalanmasının pH değerinin düşmesine, olgunlaşma esnasında laktik asidin başka ürünlere dönüşmesinin ise $\mathrm{pH}$ değerinin yükselmesine neden olabileceğini belirtmektedirler. Balkır 
(2006), eritme tuzu kullanılarak üretilen peynirin pH değerlerinin 5.78-5.81 aralığında değiştiğini bildirmiştir. Çavuş (2015), eritme tuzu kullanarak yumurta ilavesiyle elde ettiği eritme peynirlerinin $\mathrm{pH}$ aralığını 5.4 ile 5.65 arasında bulmuş, Göncü (2018), bazı baharat çeşitlerinin dilimlenebilir eritme peyniri üretiminde kullanım olanaklarının araştırılması amacıyla yaptı̆̆ çalışmada, $\mathrm{pH}$ değerinin 5.32 ile 5.64 arasında değiştiğini bildirmiştir. Doruk (2018), farklı proses tekniklerinin eritme peynirinin kalitesi üzerine etkilerini belirlemek amacıyla yaptığ çalışmalarda pH değerleri 5.17-5.56 (Eroğlu vd., 2016); 4.99-5.39 (Çetinkaya, 2012) ve 5.40-5.74 (Temizkan, 2012) arasında bulunmuştur. Bununla birlikte kaşar ve benzeri peynir türlerinde yapılan diğer araştırmalarda olgunlaşma sonunda $\mathrm{pH}$ değerlerinin düştüğü bulunmuştur bildirilmiş̧ir (Mutluer, 2007; Say, 2008; Yalman, 2011; Cankurt, 2015). Bizim çalışmamızda, pH değerinin yüksek çıkmasının peynir üretimin de kullanılan emülsifiye edici tuz varlığından kaynaklandığı düşünülmektedir.

Örneklerde yumurta oranı arttıkça protein azot değerlerinin de arttığı görülmüştür. Aynı zamanda bu artışın olgunlaşmayla devam eden proteolizin bir sonucu olduğu düşünülmektedir. Örneklerin toplam azot miktarlarının \%5.24 ile \%5.34 arasında değiş̧tiği gözlemlenmiştir. Örneklerdeki yumurta oranının artması ile toplam azot miktarının da arttığı gözlemlenmiştir. Zira yumurtada bulunan azotun artması ile, son üründe azot miktarını artırdığı kabul edilebilir. Örneklerin protein oranlarını bulabilmek için azot miktarları 6.38 sabit katsayısı ile çarpılır (Cankurt, 2015). Buna göre yapılan analizler sonucunda örneklerin protein oranları \%33.43 ile \%35. 47 arasında değişmektedir. Önceki çalışmalarda \% 18.20-33.09 aralığında bulunmuştur (Demirci, 1988; Öztek, 1989; Demirci ve Dıraman, 1990; Ayar, 1991; Kurultay ve Demirci, 1995; Erşen, 1995; Vatan, 1996; Koçak vd., 1996; Çağlar ve Çakmakçı, 1998; Güler, 2000; Yaldız, 2002; Keçeli vd., 2004; Estürk, 2004; Balkır, 2006; Ayar vd., 2006; Yaşar, 2007; Say, 2008; Yalman, 2011; Göncü, 2018 ve Cankurt, 2015). Güven vd., (2002); Güven ve Görmez, (2004) ile Göncü,. (2018) peynirin olgunlaşttkça protein değerlerinde artış olduğunu belirtmişlerdir. Bu veriler ışığında bizim çalışmamız literatür sonuçlarına benzerlik göstermektedir.

$L^{*}$ değerleri bakımından, depolama sonunda en yüksek değere sahip örnek \%10 yumurta ilaveli eritme peyniri olurken, en düşük değere sahip örnek ise kontrol peyniri olmuştur. Örneklerin $L^{*}$ değerleri 74.73 ile 81.34 arasında değişkenlik göstermiştir. Bu yükselmenin yumurtanın bileşiminde bulunan lesitinden kaynaklandığı düşünülmektedir. Peynir örnekleri vakum ambalajda depolandığ 1 için depolama süresi sonunda örneklerin $L^{*}$ değerlerinde fazla bir değişim olmamıştır. Öksüz vd. (2001) ürettikleri kaşar peynirinde $L^{*}$ değerini en düşük 74.8, en yüksek ise 90.1, olarak bulmuşlardır. Say (2008), haşlama suyunun tuz konsantrasyonu ve depolama süresinin kaşar peynirinin özellikleri üzerine etkilerini araştırmak için üretmiş olduğu kaşar peynirlerinde depolama süresi sonunda örneklerin $L^{*}$ değerini 72.91 ile 87.47 olarak bulmuştur. Çavuş (2015), peynir üretiminde tavuk yumurtası kullanımı sonucu oluşan fizikokimyasal özellikleri araştırmak için ürettiği tam yağlı eritme peynir örneklerinin L* değerlerini 86.6 ile 96.7 arasında bulmuştur. Akarca vd. (2016), baharatlı mozarella peynirinde L* değerlerini 68.46 ile 87.08 arasında, Göncü (2018), eritme peynirinde $\mathrm{L}^{*}$ değerlerini 53.53 ile 89.10 arasında tespit etmiştir. Çavuş (2015)'in sonuçlarının yaptığımız çalışmanın sonuçlarından yüksek çıkmasının nedeni, peynirdeki farklı yağ oranları ile ilişkilendirilebilir.

Örneklerin yumurta oranı arttıkça a* değerlerinin de arttığı görülmüştür. Eritme peynirlerin a* değerleri, -3.26 ile 1.74 arasında değişmiştir. En düşük değere sahip örneğin kontrol peyniri, en yüksek değere sahip örneğin ise \%10 yumurta ilaveli yağsı eritme peyniri olduğu görülmüştür. Bu sonuçlara göre, yumurta kullanılan örneklerin $\mathrm{a}^{*}$ değerinin kontrol peynirlerinin $\mathrm{a}^{*}$ değerinden yüksek olduğu görülmüştür. Bunun nedeni yumurta kullanımı ile örneklerin kırmızılık değerlerinin artmasıdır. Öksüz vd. (2001), kaşar peynirlerinde $\mathrm{a}^{*}$ değerini -0.76 ile -7.8 arasında bulmuşlardır. Fırat (2006)'nın kaşar peyniri ile ilgili yaptığı başka bir çalışmada peynirlerin $a^{*}$ değerleri -4.50 ile -4.54 arasında değişkenlik göstermiştir. Say (2008) ürettiği kaşar peynirlerinde depolama süresince $\mathrm{a}^{*}$ değerinin -8.21 ile -14.73 arasında olduğunu bildirmiştir. Cankurt (2015) ise ürettiği eritme peynirinde $\mathrm{a}^{*}$ değerini 0.40 ile 2.05 arasında bulmuş, depolamanın 30. gününde $\mathrm{a}^{*}$ değerinde artış, 60. gününde ise düşüş gözlemlediğini bildirmiştir. Çalışmamızdaki örneklerin a* değeri sonuçları, Cankurt (2015) tarafından yapılan araştırmanın sonuçları ile benzerlik göstermiştir.

Tablo 3.3. Peynirlerin depolama boyunca ölçülen renk değerleri

\begin{tabular}{|c|c|c|c|c|}
\hline & \% Yumurta & 1. Gün & 30. Gün & 60. Gün \\
\hline \multirow{4}{*}{ ב } & Kontrol & $75.39^{\mathrm{C}} \pm 0.15$ & $78.94^{\mathrm{Ab}} \pm 0.05$ & $74.73^{\mathrm{Cb}} \pm 0.01$ \\
\hline & 5 & $77.44^{\mathrm{Ba}} \pm 0.02$ & $79.53^{\mathrm{Ab}} \pm 0.65$ & $75.81^{\mathrm{Ca}} \pm 0.15$ \\
\hline & 7.5 & $77.81^{\mathrm{Ba}} \pm 0.13$ & $80.20^{\mathrm{Aa}} \pm 0.11$ & $76.80^{\mathrm{Bb}} \pm 0.11$ \\
\hline & 10 & $79.44^{\mathrm{Ab}} \pm 0.05$ & $81.34^{\mathrm{Aa}} \pm 0.26$ & $77.13^{\mathrm{Ba}} \pm 0.09$ \\
\hline \multirow{4}{*}{ * } & Kontrol & $-3.26^{\mathrm{Db}} \pm 0.04$ & $-2.61^{\mathrm{Da}} \pm 0.01$ & $-2.65^{\text {Da }} \pm 0.01$ \\
\hline & 5 & $0.26^{\mathrm{Bc}} \pm 0.03$ & $0.30^{\mathrm{Bc}} \pm 0.01$ & $0.21^{\mathrm{Ca}} \pm 0.02$ \\
\hline & 7.5 & $0.99^{\mathrm{Bb}} \pm 0.01$ & $1.17^{\mathrm{Ba}} \pm 0.02$ & $1.01^{\mathrm{Bb}} \pm 0.02$ \\
\hline & 10 & $1.60^{\mathrm{Ab}} \pm 0.01$ & $1.74^{\mathrm{Aa}} \pm 0.01$ & $1.65^{\mathrm{Ab}} \pm 0.03$ \\
\hline \multirow{3}{*}{ ڤ } & Kontrol & $18.32^{\mathrm{Dc}} \pm 0.02$ & $20.22^{\mathrm{Da}} \pm 0.01$ & $18.58^{\mathrm{Db}} \pm 0.04$ \\
\hline & 5 & $23.34^{\mathrm{Cb}} \pm 0.02$ & $24.64^{\mathrm{Ba}} \pm 0.04$ & $21.75^{\mathrm{Cc}_{ \pm}} \pm 0.04$ \\
\hline & 7.5 & $23.63^{\mathrm{Bb}} \pm 0.04$ & $26.44^{\mathrm{Ba}} \pm 0.01$ & $23.07^{\mathrm{Cc}_{ \pm}} \pm 0.02$ \\
\hline
\end{tabular}


Eritme peynirlerinde kullanılan yumurta oranı arttıkça $b^{*}$ değerlerinde de artış gözlemlenmiş olup depolama boyunca veriler arasındaki farkın istatistik olarak $(\mathrm{p}<0,05)$ önemli olduğu bulunmuştur. Peynir örnekleri arasında ilk gün ve son gün en düşük b* değerini kontrol peyniri almıştır. Yaptığımız çalışmada $b^{*}$ değerleri 18.32 ile 28.71 arasında değişkenlik göstermiştir. b* değeri sarılı̆̆ ifade ettiği için depolama sonunda en sarı örnek \%10 yumurta ilaveli yağsız eritme peyniri olmuştur. Fırat (2006), çalışmasında örneklerin $b^{*}$ değerlerinin; depolamanın 30. gününe kadar arttığı daha sonra da ise azaldığını bildirmiştir. Örneklerin $b^{*}$ değerlerini 18.40 ile 15.42 arasında bulmuştur. Öksüz vd. (2001)'in kaşar peyniri üzerine yaptıkları bir araştırmada b* değerini 19.2428.87 arasında bulmuşlardır. Eritme peynirinde b* değerini (Cankurt (2015) 19.30 ile 24.19 arasında ; (Çavuş (2015) 18.32 ile 39.12 arasında ve Göncü (2018) 22.38 ile 30.33 arasında bulmuşlardır. Bu çalışmada elde ettiğimiz değerler Öksüz vd. (2001), Cankurt (2005), Göncü (2018) ve Çavuş (2015)'in elde ettiği değerler ile benzerlik göstermektedir.

\subsection{Tekstürel Özellikler}

Depolama boyunca örneklerin sertlik değerlerinde artış görülmüştür. Beklenildiği gibi en yüksek değere sahip olan örnek kontrol peyniri iken en düşük değer gözlenen örnek ise \%10 yumurta ilaveli yağsız eritme peyniri olmuştur. Örneklerde yumurta oranı arttıkça sertlik değerlerinin azaldığı gözlemlenmiştir. Çünkü yumurta kullanımı yağı alınmış peynirlere yumuşaklık katmıştır. Çalışmamızda peynirlerin sertlik değerleri depolama boyunca artış göstermiştir. Eritme peyniri örneklerimizin sertlik değerleri $1874.4 \mathrm{~g}$ ile $3760 \mathrm{~g}$ arasında bulunmuştur. Peynirdeki yumurta oranı arttıkça sertlik değerlerinde düşüş meydana gelmiştir. Yumurta ürünün yapısını yumuşatmıştır. Depolama boyunca peynirdeki sertliği etkileyen faktörlerden birisi de pH değeridir. Kapoor ve Metzger (2008), eritme tuzlarının ve $\mathrm{pH}$ 'nın peynirin yapısında sertlik ve sıkılaşmada önemli bir rol oynadığını belirtmişlerdir. Bizim yaptığımız çalışmada da sertlik ve $\mathrm{pH}$ arasında ters orantı olduğu görülmektedir. Sertliği etkileyen bir diğer faktör yağ içeriğidir. Taze ve olgunlaşma dönemindeki peynirlerin yağ içeriği azaltıldığında sertlik değerlerinin arttığı görülmektedir (Göncü, 2018). Çavuş (2015), blok tip eritme peyniri örneklerinde sertlik değerlerini $2367 \mathrm{~g}$ ile $8059 \mathrm{~g}$ arasında bulmuş ve depolama boyunca da sertlik değerlerinde bir artış meydana geldiğini bildirmiştir. Cankurt (2015), eritme peynir örneklerinde depolamanın son gününde yapılan analizde sertlik değerlerini $1850 \mathrm{~g}$ ile $3900 \mathrm{~g}$ arasında bulmuştur. Bu sonuçlar bizim çalışmamızın sonuçlarıyla büyük oranda benzerlik göstermektedir. Göncü (2018), eritme peyniri üzerine yaptı̆̆ bir çalışmada sertlik değerlerini 3072 g ile $5161 \mathrm{~g}$ arasında bulmuş ve depolama sonunda sertlik değerlerinde düşüş gözlemiştir. Bu düşüşün nedeninin, peynirde meydana gelen proteolize olayı olduğu düşünülmektedir.

Dış yapışkanlık değeri en yüksek olan örnek \%10 yumurta ilaveli yağsız eritme peyniri olurken en düşük değere sahip örnek ise kontrol peyniri olmuştur. Eritme peyniri örneklerimizde dış yapışkanlık değerleri depolama boyunca artış göstermiştir. Bu değerler $2.04 \mathrm{~g} / \mathrm{s}$ ile $-0.46 \mathrm{~g} / \mathrm{s}$ arasında değişmiştir. Yumurta ilavesinin dış yapışkanlık değerlerini artırdığı görülmüştür. Dış yapışkanlık değerleri depolamaya bağlı olarak artmıştır ve bu artışın nedeninin, peynirde zamanla oluşan proteoliz, ve biyokimyasal olaylardaki azalmadan kaynaklandığı düşünülmektedir. Çavuş (2015), yüksek lisans tezi kapsamında ürettiği blok tip eritme peynirinde depolamaya bağlı olarak dış yapışkanlık değerlerinde artış meydana geldiğini, bazı örneklerde ise artıştan sonra tekrar düşüş meydana geldiğini bildirmiştir Göncü (2018), doktora tezi kapsamında ürettiği eritme peynirinde dış yapışkanlık değerlerinin -0.99 g/s ile -1.73 $\mathrm{g} / \mathrm{s}$ arasında değiştiğini belirtmiştir. Örneklerin dış yapışkanlık değerlerinin birbirlerinden farklı olmasının nedenini peynirlerin pH değeri, su içeriği ve enzimatik olaylara bağlamıştır. Bizim yaptığımız çalışmada tüm peynirlerin dış yapışkanlık değerlerinde artış meydana gelmiştir ve çalışma sonuçlarımız Göncü (2018) ve Çavuş (2015)'in çalışmasının sonuçlarıyla benzerlik göstermektedir.

Tablo 3.4. Peynirlerin depolama boyunca ölçülen TPA dĕgerleri

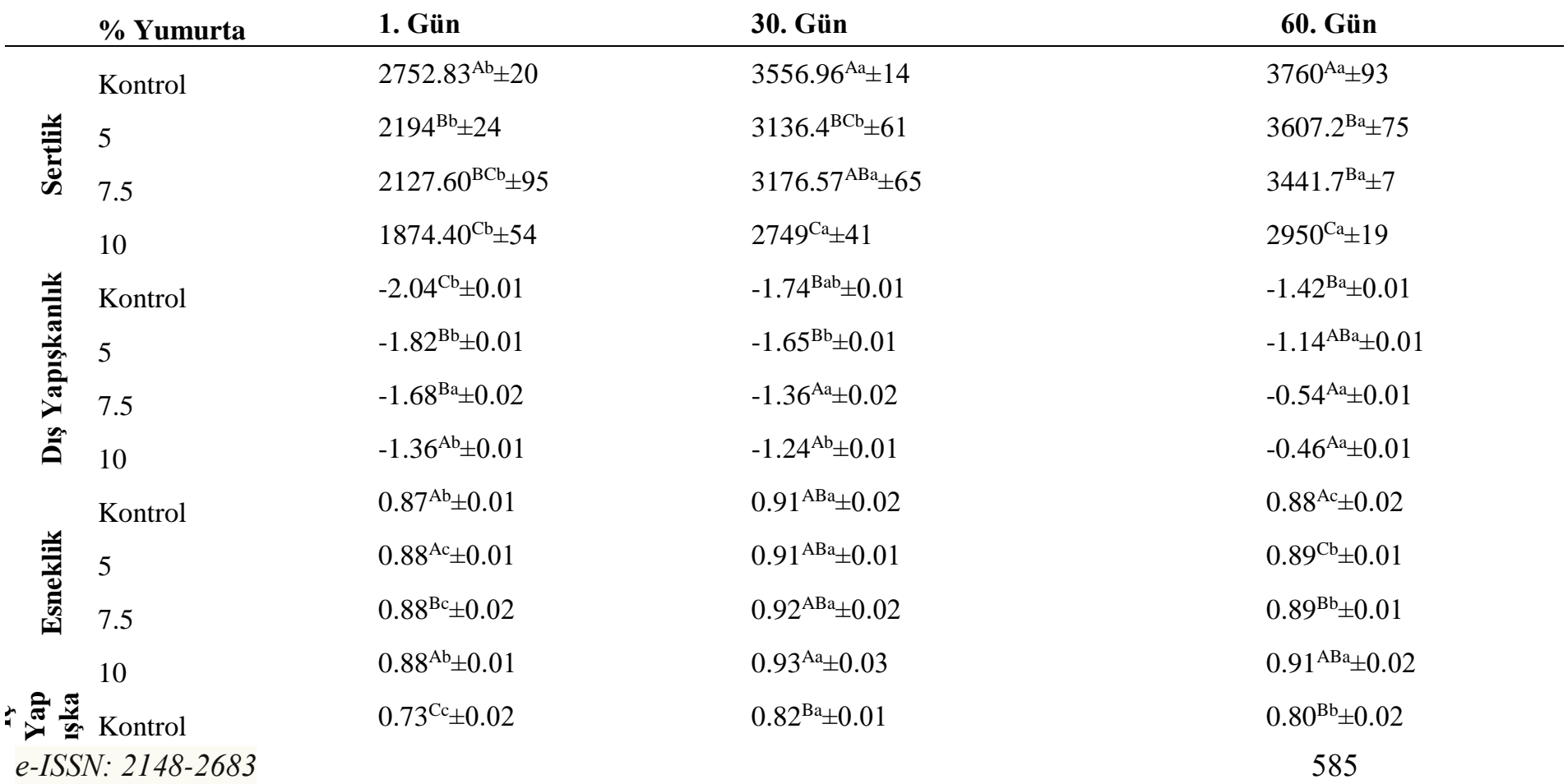




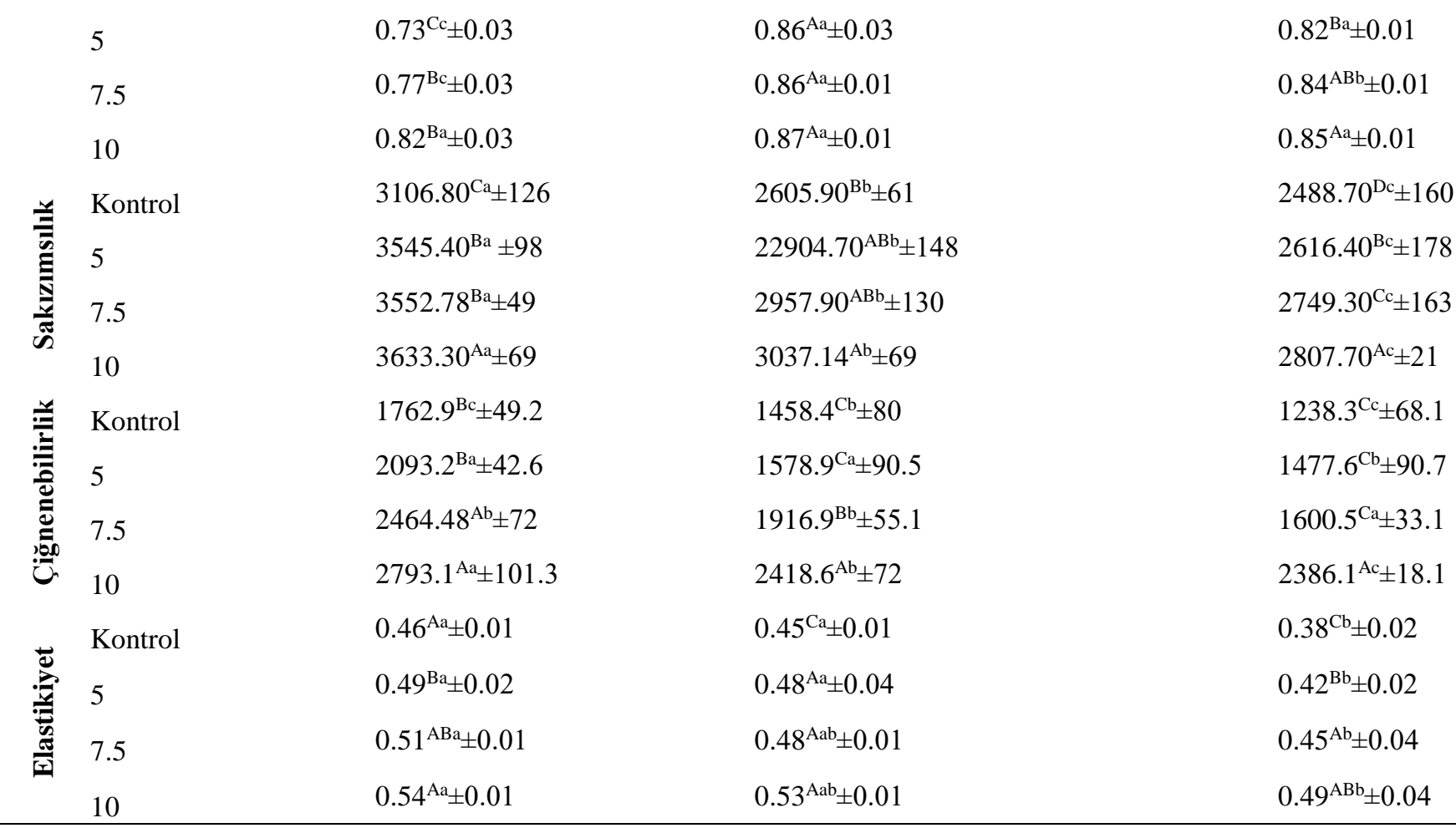

En yüksek esneklik değeri depolamanın 30. gününde \%10 yumurta ilaveli yağsı eritme peynir örneğinde görülürken, en düşük esneklik değeri ise depolamanın 1. gününde kontrol peynirinde görülmüştür Yumurta ilavesinin esneklik değerini az da olsa artırdığ 1 sonucuna ulaşılmıştır. Yaşar (2008) ürettiği kaşar peynirinde depolama boyunca esneklik değerlerinde azalma meydana geldiğini ve değerlerin 0.83 ile 0.66 arasında değişkenlik gösterdiğini bildirmiştir. Çavuş (2015), yaptığı araştırmada depolama ile esneklik değerlerinde bir azalma görüldüğünü ve değerlerin 0.865 ile 0.798 arasında olduğunu belirtmiştir. Yapılan çalışmalar ile bizim çalışmamız benzer sonuçlar göstermektedir. Cankurt (2015), yaptığı eritme peynir çalışmasında kullandığı hidrosol çeşitlerinin esnekliği arttırmadığı ancak kontrole göre esnekliğin azalmasını durdurduğunu bildirmiştir. Analiz sonucunda esneklik değerlerini 0.69-0.81 arasında bulmuştur.

İç yapışkanlık değerleri bakımından depolama boyunca en düşük değere sahip olan örnek kontrol peyniri iken (S), en yüksek değer \%10 yumurta ilaveli yağsız eritme peynirinde belirlenmiş̧tir. Eritme peynirindeki iç yapışkanlık değerleri depolama boyunca birbirine yakın bulunmuştur. Birinci gün analizlerinde eritme peynirinde yumurta oranı arttıkça iç yapışkanlık değerinin de arttığı gözlemlenmiştir. Tüm örneklerde iç yapışkanlık değerlerinde depolama süresi sonunda artış meydana gelmiştir. Koca, (2002) yağı azaltılmış kaşar peynirleri üzerine yaptı̆̆ çalışmada kontrol örneği hariç diğer örneklerin iç yapışkanlık değerlerinin depolama boyunca arttığını, kontrol örneği değerlerinde ise dalgalanmalar olduğunu bildirmiştir. Peynirlerde kullanılan yă̆ ikame maddelerinin iç yapışkanlığı artırdığını bildirmiştir. Yaptığımız çalışma sonuçları, Koca, (2003)'nin yaptığı araştırma sonuçlarıyla benzerlik göstermiştir. Çünkü yağ ikame maddesi olarak kullandığımız yumurta, eritme peynirinde iç yapışkanlık değerlerini artırmıştır. İ̧̧ yapışkanlık değerini artıran diğer bir parametre de eritme tuzlarıdır. Cankurt, (2015)'e göre bazı eritme tuzlarının peynirde iç yapışkanlı̆̆ı artırdığını bildirmiştir. Koca (2003), peynirlerin yă̆ içeriğindeki artışın iç yapışkanlık değerini azalttığını bildirmiştir. Bizim çalışmamızda da yağsız olarak üretilen eritme peynirlerinin iç yapışkanlık değerleri yüksek bulunmuştur. Göncü (2018) çalışmasında eritme peynirlerinin iç yapışkanlık değerlerinde depolama süresi boyunca azalma meydana geldiğini belirtmiştir. Bu azalmada peynirin olgunlaştırılması sırasında oluşan enzimatik, mikrobiyal ve biyokimyasal olayların etkili olduğu düşünmektedir. Cankurt (2015) ise ürettiği blok tip eritme peynirlerinde, depolama süresince iç yapışkanlık değerlerinin dalgalı bir seyir izlediğini bildirmiştir.

Depolama boyunca örneklerin sakızımsılık değerlerinde $(\mathrm{p}<0,05)$ azalma gözlemlenmiş olup en yüksek değeri alan örnek ise \%10 yumurta ilaveli yağsız örnek olmuştur. Örneklerde yumurta oranı arttırıldıkça sakızımsılık değerlerinin de arttığı gözlemlenmiştir. Blok tip eritme peynirlerinde sakızımsızlık değerleri depolama boyunca artış göstermiş olup $2488.7 \mathrm{~N}$ ile $3633.3 \mathrm{~N}$ arasında değerler almıştır. En yüksek sakızımsılık değerini alan örnek \%10 yumurta ilaveli yağsız eritme peyniri olurken en düşük değeri alan örnek ise kontrol peyniri örneği olmuştur. Genel itibari ile yumurta oranı arttıkça sakızımsılık değerinin de arttığı görülmüştür. Peynirlerin sakızımsılık değerleri ise depolama boyunca azalmıştır. Bu azalmanın nedeni peynirde meydana gelen proteolizin bir sonucu olarak protein misellerinin zayıflamasıdır. Göncü (2018) çalı̧̧masında, eritme peynirlerin sakızımsılık değerlerinin depolama boyunca azaldığını bildirmiştir. Bunun sebebinin zamana bağlı olarak proteolizin hızlanmasıyla birlikte protein matriksinin su tutmasının düşmesi ve protein misellerinde zayıflamaya bağlamıştır. Kaşar peyniri üzerine yapılan birçok araştırmada ise, peynirlerin sakızımsılık değerlerinin olgunlaşma döneminde düsstügü ve bunun proteolizle ilgili olduğu bildirilmiştir. (Akın vd., 2009; Saygıll, 2015; Eroğlu vd., 2016; Çelikel, 2017). Yapılan çalışmaların sonuçlarıyla bizim çalışmamızın sonuçları benzer özellikler göstermektedir.

Peynirde yumurta oranı arttıkça çiğnenebilirlik değerlerinin de arttığı gözlemlenmiş̧ir. En yüksek çiğnenebilirlik değerine sahip örnek \%10'luk yumurta ilaveli örnek olurken en düşük çiğnenebilirlik değerine sahip örnek ise kontrol peyniri olmuştur. Depolama e-ISSN: 2148-2683 
boyunca blok tip eritme peynirlerinin çiğnenebilirlik değerlerinde azalma görülmüşs olup, $1177.6 \mathrm{~J}$ ile $2793.1 \mathrm{~J}$ arasında değerler bulunmuştur. Koca, (2003) kaşar peynirinde yaptığı çalışmasında, peynirde yağ oranını düşürmenin çiğnenebilirlik değerini yükselttiğini bildirmiştir. Bu çalışmada elde edilen sonuçlar 4440-8890 aralığında çıkmıştır. Yine Koca, (2003)'nın bildirdiğine göre peynir örneklerinin olgunlaşma boyunca sertlik, elastiklik ve çiğnenebilirlik değerleri de düşmektedir. Yani olgunlaşma çiğnenebilirliği etkilemektedir. Bizim çalışmamızda yaptığımız eritme peynirleri haşlamaya tabi tutulduğu için olgunlaşmayı hızlandıran laktik asit bakterileri inaktive olmuştur. Bundan dolayı bizim sonuçlarımız bu araştırmacının sonuçlarından daha düşük çıkmış olabilir. Kaşar peyniri üzerine yapılan birçok çalışmada, çiğnenebilirlik değerlerinin depolama boyunca düştügü bildirilmiştir (Koca, 2003; Yerlikaya, 2008; Akın vd..., 2009; Saygıl1, 2015). Göncü (2018) çalışmasında, eritme peynirlerinin çiğnenebilirlik değerlerinin iç yapışkanlık ve elastiklik değerlerine paralel olarak depolama boyunca azaldığını bildirmiştir. Bu durumun depolamaya bağlı olarak gelişen proteoliz sonucu, kazein ağındaki zayıflamadan kaynaklandığını bildirmiştir. Yaptı̆̆ımız çalışmada, literatürde geçen çalışmaların sonuçlarına benzer sonuçlar bulunmuştur.

En yüksek elastikiyet değerine sahip örnek \%10 yumurta ilaveli yağsız eritme peyniri iken en düşük kontrol eritme peyniri olmuştur. $\mathrm{Bu}$ sonuçlardan da anlaşılacağı üzere peynire yumurta ilavesi elastikiyet değerlerini olumlu yönde artırmıştır. Depolama boyunca örneklerde elastikiyet değerlerinde azalma gözlemlenmiş olup, örnekler arasındaki fark istatistiksel olarak $(\mathrm{p}<0,05)$ önemli bulunmuştur. Peynirlerde olgunlaşma boyunca elastiklik değerlerinin azalmasının nedeni, peynirin proteolizi sonucu serbest su miktarının azalması, protein degradasyonu ve yă̆ globüllerinin sıkılaşması ile ilişkilidir (Ghoddushi ve Robinson, 1996). Bizim çalı̧mamızda da depolama boyunca örneklerin elastikiyet değerlerinde azalma meydana gelmiştir. Bu azalmanın proteinlerin proteolizinden kaynaklandığ 1 düşünülmektedir. Koca (2003), yağ ikame maddeleri kullanarak üretmiş olduğu kaşar peyniri örneklerinde ortalama elastikiyet değerlerini yağlı peynir için 0.27 yağı azaltılmış peynir için de 0,56 bulmuştur. Peynir kitlesindeki protein artışının sonucunda elastikiyet değerinde de artış meydana geldiği bildirilmiştir. Yaptı̆̆ımız çalışmada da bu durumu destekleyen sonuçlar bulunmuştur. Solak (2013), eritme tipi peynirler üzerine yaptığı çalışmasında peynirlerin elastikiyet değerlerinin peynirin olgunlaşması süresince gerçekleşen biyokimyasal olaylardan ve emülsifiye edici tuzlardan etkilenebileceğini bildirmiştir. Cankurt (2015) ve Çavuş (2015)'in ürettikleri eritme peynirlerinde elastikiyet değerlerinin depolama boyunca düştüğü görülmüştür. Göncü (2018), eritme peyniri üzerine yaptığı çalışmasında, baharat ilaveli blok tip eritme peynirlerinin elastiklik değerlerinin olgunlaşma süresince düzenli bir azalma gösterdiğini bildirmiştir. Bu azalmayı, baharatların peynirin kuru maddesini artırmasına bağlamıştır. Elde ettiğimiz sonuçlar yapılan çalışmaların sonuçları ile benzerlik göstermektedir.

\subsection{Duyusal Analiz Sonuçları}

Blok tip eritme peyniri örneklerinin tamamı, görünüş özellikleri bakımından yüksek puanlar almıştır. Eritme peynirleri arasında görünüş özellikleri bakımından en yüksek puanları \%7.5 ile \%10 yumurta ilaveli yağsız peynir örnekleri alırken en düşük puanı ise, kontrol eritme peynir örneği almıştır. Peynirler içerisinde en beğenilen örneklerin \%7.5 yumurta ilaveli peynir ile \%10 yumurta ilaveli peynir olmasının sebebinin yumurtanın ürüne sarı bir renk kazandırmasının bir sonucu olduğu kabul edilebir. Güven vd. (2002), Çürük (2006), Yaşar (2008) ve Göncü (2018) yaptıkları çalışmalarda depolama süresinin sonunda görünüş puanlarında düşüş meydana geldiğini bildirilmişlerdir. Yine Çavuş (2015) ürettiği blok tip eritme peynirlerinin görünüş değerlerinde depolama boyunca dalgalanma olmasına rağmen depolama sonunda görünüş değerlerinde düşüş meydana geldiğini bildirmiştir. Bizim araştırmamızda da görünüş değerleri depolama boyunca azalmıştır.

Tablo 3.5. Peynirlerin depolama boyunca ölçülen duyusal özellikleri

\begin{tabular}{|c|c|c|c|c|}
\hline & $\%$ Yumurta & 1. Gün & 30. Gün & 60. Gün \\
\hline \multirow{4}{*}{ نُ } & Kontrol & $8.61^{\mathrm{Aa}} \pm 0.02$ & $8.39^{\mathrm{Ba}} \pm 0.04$ & $8.28^{\mathrm{Ba}} \pm 0.04$ \\
\hline & 5 & $8.56^{\mathrm{Aa}} \pm 0.04$ & $8.39^{\mathrm{Ba}} \pm 0.02$ & $8.22^{\mathrm{Ba}} \pm 0.04$ \\
\hline & 7.5 & $8.72^{\mathrm{Aa}} \pm 0.04$ & $8.61^{\mathrm{Aa}} \pm 0.02$ & $8.39^{\mathrm{Aa}} \pm 0.04$ \\
\hline & 10 & $8.78^{\mathrm{Aa}} \pm 0.04$ & $8.50^{\mathrm{ABb}} \pm 0.01$ & $8.33^{\mathrm{Ab}} \pm 0.01$ \\
\hline \multirow{4}{*}{ 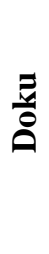 } & Kontrol & $8.33^{\mathrm{Ba}} \pm 0.02$ & $8.27^{\mathrm{Ba}} \pm 0.02$ & $8.13^{\mathrm{Ba}} \pm 0.02$ \\
\hline & 5 & $8.67^{\mathrm{Aa}} \pm 0.02$ & $8.33^{\mathrm{ABb}} \pm 0.02$ & $8.20^{\mathrm{ABb}} \pm 0.01$ \\
\hline & 7.5 & $8.73^{\mathrm{Aa}} \pm 0.02$ & $8.53^{\mathrm{ABab}} \pm 0.02$ & $8.23^{\mathrm{ABb}} \pm 0.02$ \\
\hline & 10 & $8.67^{\mathrm{Aa}} \pm 0.02$ & $8.47^{\mathrm{Aab}_{ \pm}}+0.02$ & $8.36^{\mathrm{Ab}} \pm 0.02$ \\
\hline \multirow{4}{*}{ } & Kontrol & $7.86^{\mathrm{Ca}} \pm 0.03$ & $7.60^{\mathrm{Ba}} \pm 0.02$ & $7.53^{\mathrm{Ba}} \pm 0.02$ \\
\hline & 5 & $8.33^{\mathrm{Ba}} \pm 0.02$ & $8.13^{\mathrm{ABab}_{ \pm} 0.02}$ & $7.80^{\mathrm{ABb}} \pm 0.01$ \\
\hline & 7.5 & $8.60^{\mathrm{Aa}} \pm 0.01$ & $8.40^{\mathrm{Aa}} \pm 0.01$ & $8.13^{\mathrm{Bb}} \pm 0.01$ \\
\hline & 10 & $8.33^{\mathrm{Aa}} \pm 0.02$ & $8.00^{\mathrm{ABb}_{ \pm}} \pm .01$ & $7.73^{\mathrm{Bc}} \pm 0.01$ \\
\hline
\end{tabular}

Doku değerlerinde ilk günden son güne kadar en yüksek puanı alan örnek \%7.5 yumurta ilaveli yağsız eritme peyniri iken, en düşük puanı alan örnek ise kontrol peyniri olmuştur. Depolama sonunda örneklerin doku değerleri arasındaki farkın istatistiksel olarak ( $<<0.05)$ önemli olduğu görülmüştür. Tunçtürk (1996), farklı enzimler kullanarak ürettiği starter kültürlü kaşar peynirlerinin 
depolanması sonucu örneklerin doku değerlerinde düşüş meydana geldiğini görmüştür. Bu düşüşün örneklerdeki asitlik değerlerinin düşmesine bağlı olduğunu ve bu durumun sonucu olarak peynirin sıkı ve kırılgan bir yapı kazandığını bildirmiştir. Yapıdaki sıkılık ve kırılganlığın nedenini de, örneklerin pH'larının kazeinin izoelektrik noktasına yaklaşması sonucu, misellerin kısalması ve kazein matriksinin büzülmesine bağlamıştır. Güven vd. (2002), Solak (2013), Çavuş (2015) ve Göncü (2018) yaptıkları çalışmalarda olgunlaşma boyunca peynirlerin doku puanlarının düştüğünü görmüşlerdir.

Depolama boyunca en yüksek lezzet değerine sahip örnek \%7,5 yumurta ilaveli yağsız eritme peyniri olurken, en düşük lezzet değerine sahip örneğin ise kontrol peyniri olduğu görülmüştür. Sadece \%7.5 yumurta ilaveli yağsız eritme peyniri ilk günden son güne kadar tüm zamanlarda 8 puanın üzerinde puan almıştır. \%5 ile \%10 yumurta ilaveli yağsız eritme peynirlerinin birbirine yakın değerler aldığı görülmüştür. Depolama sonunda örneklerin lezzet değerleri arasındaki farkın istatistiksel olarak $(p<0.05)$ önemli olduğu görülmüş̧ür. Peynirden yağın alınması, telemeden elde edilen eritme peynirinin, yağdan gelen lezzetin ve peynirin kendine has sarı renginin kaybolmasına neden olmuştur. Bunun sonucu olarak mat renkli ve yavan bir ürün ortaya çıkmıştır. Yapılan çalışmalara göre birçok peynirde depolama boyunca lezzet puanlarında görülen düşüşün nedeninin, proteoliz, laktoz fermantasyonu, ve uçucu bileşiklerin oluşumuna yardımcı olan çeşitli biyokimyasal değişiklikler olduğu bildirilmiştir (Krıstoffersen, 1985; Lyne, 1995). Fox vd. (1996) ve Fox ve McSweeney (1996) peynirin kendine has lezzet ve aromasının oluşumunda para-k-kazeinin parçalanmasıyla meydana gelen bileşiklerin oluşturduğu değişikliklerin etkili olduğunu bildirmişlerdir. Cankurt (2015), Çavuş (2015), Çürük (2006), Göncü (2018) ve Yaşar (2007) ürettikleri peynirlerde depolama süresi boyunca lezzet puanlarının düştüğünü bildirmişlerdir.

\section{Sonuç}

Tüm örnekler içinde kuru madde oranı en fazla olan örnek \%10 yumurta ilaveli eritme peynir olurken, en düşük kuru madde oranına sahip örneğin ise kontrol peyniri olduğu görülmüsştür. Yumurta oranı arttıkça örneklerin kuru madde değerleri de artmaktadır. Çalışmamızda üretilen eritme peynirleri yağsız sütten elde edildiğinden dolayı yağ oranı önemsiz bulunmuştur. İlk günkü değerler incelendiğinde tüm peynirlerde tuz oranı \% 1.78-1.79 arasında bulunmuştur. Tüm örnekler içinde tuz oranı en fazla olan örnek \%10 yumurta ilaveli eritme peyniri olurken, en düşük tuz oranına sahip örneğin ise peyniri olduğu görülmüsşür. Eritme peynirlerinin asitlik değerleri incelendiğinde en yüksek asitliğe sahip peynirin \%10 yumurta ilaveli eritme peyniri olduğu görülmüştür. Eritme peynirine ilave edilen yumurtanın asitlik değerlerini yükselttiği görülmüştür. Eritme peynirlerine yumurta ilave edilmesinin asitliği yükseltmesi ile aynı oranda $\mathrm{pH}$ değerlerinin önemli düzeyde $(\mathrm{p}<0.05)$ düştüğü görülmüştür. Peynirlerin azot değerleri olgunlaşma süresi boyunca önemli düzeyde $(p<0.05)$ artış göstermiştir. Eritme peynirlerinin $L^{*}, a^{*}$ ve $b^{*}$ değerlerinde olgunlaşma süresince dalgalanmalar görülmüştür. Örnekler içerisinde $L^{*}, a^{*}$ ve $b^{*}$ değerleri en yüksek peynir $\% 10$ yumurta ilaveli eritme peyniri olurken, en düşük değerlere sahip örnek ise yağsız eritme peyniri olmuştur. Örneklerin tekstür değerleri incelendiğinde dış yapışkanlık, esneklik, iç yapışkanlık, sakızımsılık, çiğnenebilirlik ve elastikiyet paramatrelerinin benzer değişimler göstererek en yüksek değerlere sahip örneğin \%10 yumurta ilaveli eritme peyniri iken en düşük değerlere sahip örneğin ise yağsız eritme peyniri olduğu görülmüştür. Bununla beraber sertlik değeri en yüksek örnek yağsız eritme peyniri iken en düşük \% 10 yumurta ilaveli eritme peyniridir. Depolama boyunca örneklerin sertlik değerlerinde önemsiz düzeyde ( $>0.05)$ azalma olduğu gözlemlenmiştir. Buna göre yumurta kullanımı peynirlerin sertlik değerlerini düşürmüştür. Duyusal açıdan örnekler değerlendirildiğinde yumurta kullanımının genel beğeniyi arttırdığı görülmüştür. Duyusal analizlerin tüm parametrelerinde en yüksek değeri alan örnek \%7.5 yumurta ilaveli eritme peyniri olmuştur. Sonuç olarak eritme peyniri üretiminde yumurta kullanılmasının peynirlerin tekstürel ve duyusal özelliklerine olumlu katkı sağladığı anlaşılmıştır. Aynı zamanda yumurta kullanımı eritme peynirinin raf ömründe herhangi bir değişikliğe neden olmamaktadır.

\section{Kaynakça}

Ahmed, N.H., El Soda, M., Hassan, A.N., Frank, J., 2005. Improving the textural properties of an acid-coagulated (karish) cheese using exoploysaccharide producing cultures, LWT Food Science and Technology, (38), 843-847.

Akarca, G., Çağlar, A., Tomar, O., 2016. The effects spicing on quality of mozzarella cheese. Mljekarstvo, 66 (2): 112-121.

Akın, M. S., Akın M. B., Atasoy F., Kırmacı, H. A. Kırmacı Z., 2009. Sodyum alginat, karragenan ve gellan sakızı kullanılarak emülsiyon ve ekstrüzyon yöntemleri ile kapsüllenmiş enzimlerin (proteaz, lipaz ve proteaz/lipaz karışımı) kaşar peynirinin hızlı olgunlaştırılmasında kullanım olanaklarının araştırılması. Tubitak Araştırma Projesi. Proje No: $106 \mathrm{O} 409$.

Alper, İ., 2012. Eritme Peynirinde Farklı Baharat İlavesinin Escherichia Coli Ve Staphylococcus Aureus Üzerine İnhibasyon Etkisi. (Yükseklisans tezi), Namık Kemal Üniversitesi Fen Bilimleri Enstitüsü, Tekirdağ.

Anonim, 2016, Ulusal Süt Konseyi, 2016. Süt Raporu, (50-11)s.

Atamer, M., Koçak, C., Çimer, A., Odabaşı, S., Tamuçay, B., Yamaner, N., 1999.Some quality characteristics of kashar cheese manufactured from milk preserved by activation of lactoperxidase/thiocyanate/hydrogen peroxide (lp) system. Milchwissenschaft, 54 (10):553-556.

Ayar, A. 1991. Trabzon ili dâhilinde tüketime sunulan kaşar peynirlerinin tüzük ve standarda uygunluğu. Ondokuz Mayıs Üniversitesi, Fen Bilimleri Enstitüsü, Gıda Mühendisliği ABD, Yüksek Lisans Tezi, Trabzon.

Ayar, A., Akun, N., Sert, D. 2006. Bazı peynir çeşitlerinin mineral kompozisyonu ve beslenme yönünden önemi. 9. Gıda Kongresi, 24-26 Mayis, Bolu, Türkiye.

Balkır, P., 2006. Taze Kaşar Peynirlerine Yapılan Hilelerin Belirlenmesi ve Taklit Taze Kaşar Peynirlerinin Ayırt Edilme Yöntemleri Üzerine Bir Araştırma.( Doktora Tezi), Ege Üniversitesi Fen Bilimleri Enstitüsü, İzmir.

Cankurt, H., 2015. Bazı Bitki Su Ve Uçucu Yağların Blok Tipi Eritme Peyniri Ve Beyaz Peynirin Çeşitli Özellikleri Üzerine Etkisi. Doktora Tezi, Erciyes Üniversitesi Fen Bilimleri Enstitüsü, Kayseri. 
Çağlar, A., Çakmakçı, S. 1998. Kaşar peynirinin hızlı olgunlaştııılmasında proteaz ve lipaz enzimlerinin farklı metotlarla kullanımı. Gida 23 (4): 291-301

Çavuş, M., 2015. Blok Tip Eritme Peyniri Üretiminde Tavuk Yumurtası Kullanımının Peynirin Fizikokimyasal, Tekstürel Ve Duyusal Özellikleri Üzerine Etkisi. Yüksek Lisans Tezi, Iğdır Üniversitesi, Fen Bilimleri Enstitüsü, Gıda Mühendisliği Anabilim Dalı, Iğdır

Çelik, S.., Uysal Ş., 2009. Beyaz peynirin bileşim, kalite, mikroflora ve olgunlaşması. Atatürk Üniversitesi Ziraat Fakültesi Dergisi, 40 (1), 141-151.

Çelikel, A., 2017. Yenilebilir Film ve Çeşitli Baharat Karışımlarının Optimizasyonu ve Eritme Peynirlerinin Kaplamasında Kullanım Olanakları. Harran Üniversitesi, Fen Bilimleri Enstitüsü, Doktora Tezi, Şanlıurfa, 167s

Çetinkaya, A., 2012. Kaşar Peynirinde Farklı Tuzlama ve Muhafaza Yöntemlerinin Peynirin Kalitesi Üzerine Etkisi. Atatürk Üniversitesi, Sağlık Bilimleri Enstitüsü, Doktora Tezi, Erzurum, 230s

Çürük M., 2006. Kaşar Benzeri Peynirlerin Bazı Özellikleri Üzerine Eritme Tuzu Kullanımının Ve Olgunlaşma Süresinin Etkileri. Doktora Tezi, Çukurova Üniversitesi, Fen Bilimleri Enstitüsü, Gıda Mühendisliği Anabilim Dalı, Adana.

Demirci, M., 1988. Ülkemizin önemli peynir çeşitlerinin mineral madde düzeyi ve kalori değerleri. Gıda, 13 (1), 17-21

Demirci, M. ve Dıraman, H., 1990. Trakya bölgesinde üretilen vakum paketlenmiş taze kaşar peynirlerinin yapım tekniği fiziksel, kimyasal ve mikrobiolojik nitelikleri ve enerji değerleri üzerinde bir çalışma. Trakya Üniversitesi Tekirdağ Ziraat Fakültesi Tarım Ürünleri Teknolojisi Bölümü, Tekirdağ, 83-88.

Dolun, Y., Kaşar, Beyaz, Tulum ve Lor Peynirlerinden Çeşitli Karışım ve Oranlarda Yapılan Eritme Peynirleri Üzerinde Araştırmalar. Doktora Tezi, Ankara. (1974)

Doruk, İ.,2018 Farklı Proses Tekniklerinin Eritme Peyniri Yapımında Ürün Kalitesi Üzerine Etkilerinin Belirlenmesi. Yüksek lisans tezi, Namık Kemal Üniversitesi Fen Bilimleri Enstitisü, Tekirdağ

Drake, M. A.; Swanson, B.G., 1995. Reduced and low fat cheese technology, Trends İn Food Science And Technology, 6:366-369

Erşen, N., 1995. Ankara Piyasasında Satılan Kaşar Peynirlerinin Proteoliz Düzeyi Üzerinde Bir Araştırma. Yüksek lisans tezi, Ankara Üniversitesi, Fen Bilimleri Enstitüsü Ankara.

Eroglu, A., Toker Ö., S. And Dogan, M., 2016. Changes in the texture, physicochemical properties and volatile compound profiles of fresh kashar cheese during ripening. International Journal of Dairy Technology, 69(2): 243-453.

Estürk, O., 2004. Functional and textural properties of the selected turkish cheeses resent development in dairy science and technology international dairy symposium proocedings: 257-259, May 24-28 Isparta, Turkey

Farkye, N.Y. and FOX, P.F., 1990. Objective indices of cheese ripening. Trends İn Food Science and Technology, 1 (2): 37-40.

Fırat, N. 2006. Çiğ ve pastörize sütten üretilen kaşar peynirlerinin olgunlaşma süresince bazı mikrobiyolojik, fiziksel ve kimyasal özelliklerinin belirlenmesi. Atatürk Üniversitesi, Fen Bilimleri Enstitüsü, Gıda Mühendisliği ABD, Yüksek Lisans Tezi, Erzurum.

Fox, P.F. and McSweeney P.L.H., 1996. Proteolysis in cheese during ripening. Food Reviews International, 12, 457- 509

Göncü, B., 2018. Bazı Baharat Çeşitlerinin Dilimlenebilir Eritme Peyniri Üretiminde Kullanım Olanaklarının Araştııılması. Doktora Tezi, Harran Üniversitesi Fen Bilimleri Enstitüsü, Şanlıurfa.

Ghoddusi, H. B., \& Robinson, R. K. (1996). Enumeration of starter cultures in fermented milks. Journal of Dairy Research, 63(1), 151-158.

Güler, Z., 2000. Beyaz, Kaşar Ve Tulum Peynirlerinin Serbest Yağ Asitleri İle Duyusal (Tat-Koku) Nitelikleri Arasındaki İlişkiler Üzerine Bir Araştırma. (Doktora Tezi), Ankara Üniversitesi, Fen Bilimleri Enstitüsü, Ankara.

Güven, M., Karaca, O.B., Var, I., Kaçar, A. ve Hayaloğlu, A.A., 2002. Antimikrobiyal madde kullanımının ve ambalaj materyalinin olgunlaşma süresince kaşar peynirinin özellikleri üzerine etkisi. HR.Ü.Z.F. Dergisi, 6 (1-2): 13-25.

Güven, M., Tatar, N., Görmez, P., 2004. Antimikrobiyel madde kullanımı ve paketleme materyalinin kaşar peynirinin bazı özellikleri üzerine etkileri. Gida ve Yem Bilimi Teknolojisi, 5: 3 - 11.

Hui, Y.H., 1992, Dairy science and technology handbook. VCH Publishers, 220. East 23rdStreet, N.York, Newyork, 10010, p.435

Idf., 1993. Milk determination of the nitrogen (kjeldahl metod) and calculation of the crude protein content. IDF Standard 20B, Brussels: International Dairy Federation.

Kapoor, R. and Metzger, L.E., 2008. Process cheese: scientific and technological aspects a review comprehensive reviews in food science and food safety, 7,(2),194-214

Keçeli, T., Şahan N. and Yaşar, K., 2006. The Effect of pre-acidification with citric acid on reduced-fat kashar cheese. The Australian Journal of Dairy Technology, 61 (1): 32-36.

Keleş, A., Atasever, M., Güner, A. ve Uçar, G., 2001. İnek ve koyun sütünden üretilen ve farklı ambalajlarda olgunlaştırlan hellim peynirinin bazı kalite nitelikleri. Gida, 26 (1):61-70. Ankara.

Koca, N., Metin, M., 2003. Bazı yăg ikame maddelerinin taze kaşar peynirinin bazı nitelikleri üzerine etkileri. Süt Endüstrisinde Yeni Eğilimler Sempozyumu, 8: 63 - 68.

Koçak, C., Bitlis, A., Gürsel, A. and Avşar, Y.K., 1996. Effects of Added fungal lipase on the ripening of kashar cheese. Milchwissenschaft, 51, (1): 13- 17.

Kristoffersen, T., 1985. Development of flover in cheese. Milchwissenschaft 40:197- 199.

Kurt, A., Çakmakçı, S., Çağlar, A., 1996. Süt ve mamülleri analiz metotları rehberi, Atatürk Üniversitesi Yayınları, (18)s.

Kurultay, Ş. ve Demirci, M., 1996. Çiğ sütten ve pastörize süte değişik kültür kombinasyonları ilavesi ile yapılan vakum paketlenmiş kaşar peynirleri üzerine bir araştırma. Tekirdağ Zir. Fak. Dergisi, 4:35-44.

Lyne, J., 1995. İmproving cheese flovour. in 4th cheese symposium, national dairy products research centre, moorepark, pp.46-50. Fermoy Co., Cork. 
Mahfouz, M.B., El-Dien, H.F., El-Shibiny, S., Haggag, H.F. and M.N. Magdoub,1986. Chemical and microbiological quality of market processed cheese. Egyptian J. Dairy. Sci., 14(1) (1986) 33-41.

Metin, M., 2010. Süt ve mamülleri analiz yöntemleri, Ege Üniversitesi, Ege Meslek Yüksekokulu Yayınları, 94 s

Metin, M. ve Öztürk, G.F., 1991. Türkiye'de vakum paketlenmiş taze kaşar peynirlerinin yapımı ve düşündürdükleri. 'Milli Süt ve Süt ürünleri Sempozyumu. Trakya Ünv. Tekirdağ Ziraat Fak. Yayın no:125, 158-180

Mistry, V. V., Metzger, L. E. 1994. Application of cream homogenization in reduced fat processed cheese manufacture. Journal of Dairy Science, Supplement 1.

Mitsumoto, M. O'grady, M.N., Keery, J.P., Buckley, D.J. 2005. Addition of tea catechins and vitamin C on sensory evaluation, colour and lipid stability during chilled storage in cooked or raw beef and chicken patties, Meat Science 69, 773-779.

Mutluer, U. 2007. Uygulanan Bazı Farklı İşlemlerin Sünme Peynirinin Özellikleri Üzerine Etkisi. Yüksek lisans tezi, Çukurova Üniversitesi Fen Bilimleri Enstitüsü, Gida Mühendisliği ABD, Adana.

Öksüz, Ö., Kurultay, S., Şimşek, O., 2001. The effect of brevibacterium linens on some physico-chemical properties and colour intensity of kashar cheese. Milchwissenschaft, 56(2):82-85.

Öksüztepe, G., Patır, B., Dikici, A. ve İlhak., 2009. Elazığ'da tüketime sunulan vakum paketli taze Kaşar peynirlerinin mikrobiyolojik ve kimyasal kalitesi. F.Ü. Sağ. Bil. Vet. Derg., 23 (2): 89-94.

Özdemir, C. 1997. Soğutulmuş $\left(4 \pm 1^{\circ}\right.$ C) Sütlerden Üretilen Kaşar Peynirlerine Sorbat Katılmasının Etkileri. Trakya Üniversitesi, Fen Bilimleri Enstitüsü, Doktora Tezi, Edirne.

Özkan E. R., 2012. Farklı pH Değerlerindeki Peynirlerden Blok Tip Eritme Peynir Üretim Şartlarının Ve Ürün Özelliklerinin Belirlenmesi. Yüksek lisans tezi, Gıda Mühendisliği Anabilim Dalı, Konya

Öztek, L., 1989. Kaşar peynirinde uçucu yağ asitlerinin tayini üzerinde araştırmalar, Gıda 14 (3), 149-154)

Rudan, M.A., Barbano, D.M., Yun, J.J., Kindstedt, P.S., 1999. Effect of fat reduction on composition, proteolysis, functionality and yield of Mozarella cheese, Journal of Dairy Science, 82:661-662.

Saldamlı, İ., 1987. Eritme peyniri ve çeşitleri. Tarım Orman ve Köyişleri Bakanlığı, Ankara İl Kontrol Laboratuar Müdürlüğü, Yayın No:7, Ankara (1987)

Say, D., 2008. Haşlama Suyunun Tuz Konsantrasyonu Ve Depolama Süresinin Kaşar Peynirinin Özellikleri Üzerine Etkileri. Doktora Tezi, Çukurova Üniversitesi Fen Bilimleri Enstitüsü, Gıda Mühendisliği ABD, Adana.

Saygıll, D., 2015. Mersin Uçucu Yağı İçeren Yenilebilir Film Üretimi ve Kaşar Peynirinin Muhafazasında Mikrobiyel İnaktivasyona Etkisi. Ege Üniversitesi, Fen Bilimleri Enstitüsü, Yüksek Lisans Tezi, İzmir, 98s

Solak, B.B., 2013. Farklı Tip Peynirler Kullanılarak Üretilen Eritme Tipi Peynirlerin Üretimi Esnasında Uygulanan İşlem Parametrelerinin Peynirin Bazı Özellikleri Üzerine Etkisi. (Doktora Tezi), Selçuk Üniversitesi Fen Bilimleri Enstitüsü, Gıda Mühendisliği ABD, Konya

Tekinşen, C., Tekinşen, K., 2005. Süt Ürünleri Teknolojisi. Selçuk Üniversitesi Veteriner Fakültesi Yayınları. Konya

Temizkan, R. 2012. Kaşar Peynirinin Bileşim, Proteoliz, Fonksiyonel ve Duyusal Özellikleri Üzerine İnek, Koyun ve Keçi Sütü Kullanımının Etkisi. Çanakkale Onsekiz Mart Üniversitesi, Fen Bilimleri Enstitüsü, Yüksek Lisans Tezi, Çanakkale, 85 s.

Tunçtürk, Y. 1996. Kaşar Peynirinin Starter Kültür, Proteinaz Ve Lipaz Enzimleri İlavesiyle Hızlı Olgunlaştırılması Üzerinde Bir Araştırma. Yüzüncü Yıl Üniversitesi, Fen Bilimleri Enstitüsü, Gıda Mühendisliği ABD, Doktora Tezi, 140 s.

Vatan, T., 1996. Bursa İl Merkezinde Satışa Sunulan Kaşar Peynirlerinin Kimyasal Ve Mikrobiyolojik Özellikleri Üzerine Araştırmalar. Yüksek lisans tezi, Uludağ Üniversitesi Fen Bilimleri Enstitüsü, Gıda Mühendisliği Anabilim Dalı, Bursa

Yaldız, O., 2002. Kırklareli il merkezinde tüketime sunulan taze ve eski kaşarların kimyasal bileşimlerinin ve hijyenik kalitesinin belirlenmesi üzerine bir araştırma. Gıda ve Yem Bilimi-Teknolojisi, 2 : 20- 27. Bursa.

Yalman, M., 2011. Kaşar Benzeri Peynir Üretimi: Fiziksel, Kimyasal Ve Duyusal Özellikleri. Yüksek lisans tezi, Çanakkale On Sekiz Mart Üniversitesi Fen Bilimleri Enstitüsü, Çanakkale.

Yaşar, K., 2008. Farklı Pıhtılaştırıcı Enzim Kullanımının Ve Olgunlaşma Süresinin Kaşar Peynirinin Özellikleri Üzerine Etkisi. Doktora tezi, Çukurova Üniversitesi Fen Bilimleri Enstitüsü, Adana

Yasar, K. And Guzeler, N., 2011. Effects of coagulant type on the physicochemical and organoleptic properties of kashar cheese. Int. J. Dairy Technol., 64: 372-379.

Yerlikaya, O. 2008. Kaparili Beyaz Peynir Üretimi Ve Kalite Özellikleri Üzerine Bir Araştırma. Ege Üniversitesi Ziraat Fakültesi Süt Teknolojisi ABD, Yüksek Lisans Tezi, İzmir.

Yetim, H. 2001. Gıda analizleri, Atatürk Üniversitesi, Ziraat Fakültesi, Ofset Tesisi, Yayın No: 227, Erzurum.

Yöney, Z., 1962. Memleketimizde işlenen bazı avrupa tipi peynirlerin genel özellikleri üzerinde araştırmalar. Ankara Üniv. Zir. Fak. Yıllığı, Sayı: 12, (1962) 181-193. 